\title{
A Journey into the European Supply Chains: Key Industries and Best Practices
}

\author{
Elena Pessot, Irene Marchiori, Andrea Zangiacomi, and Rosanna Fornasiero
}

\begin{abstract}
Macro-trends and sectoral-specific evolutions are changing the way companies produce, distribute and build relationships in their supply network and with customers. Aiming to investigate the effective implementation of new supply chain concepts and innovation needs identified in the previous sections, this chapter provides a study of multiple cases of excellence among European supply chains. It depicts an overview of major trends and structural features of 8 key industries for European economy, i.e. Automotive, Aerospace, Fashion, Chemical, IT, Distribution/logistics, Furniture, Food and Beverage. For each industry, a structured investigation into one or more companies was performed with a total of 18 companies involved. The results identify possible matchings in relation to supply chain strategies, and good and best practices adopted accordingly.
\end{abstract}

Keywords Products and services $\cdot$ Sourcing $\cdot$ Production process $\cdot$ Supply chain configuration $\cdot$ Customer relationship $\cdot$ Cross-sectoral analysis $\cdot$ Multiple case study

E. Pessot $(\varangle) \cdot$ I. Marchiori · A. Zangiacomi · R. Fornasiero

Institute of Intelligent Industrial Technologies and Systems for Advanced Manufacturing, National Council of Research (STIIMA-CNR), Via Alfonso Corti, 12-20133 Milan, Italy e-mail: elena.pessot@stiima.cnr.it

I. Marchiori

e-mail: irene.marchiori@ieiit.cnr.it
A. Zangiacomi
e-mail: andrea.zangiacomi@stiima.cnr.it
R. Fornasiero
e-mail: rosanna.fornasiero@cnr.it
I. Marchiori $\cdot$ R. Fornasiero

Institute of Electronics, Computer and Telecommunication Engineering, National Council of Research (IEIIT-CNR), c/o Università di Padova, via Gradenigo 6/B, 35131 Padova, Italy

R. Fornasiero et al. (eds.), Next Generation Supply Chains, 


\section{Introduction to Empirical Analysis of European Supply Chains}

Following the analysis of the macro-trends, expected future scenarios and supply chain strategies identified as most relevant for the supply chains of the future, this chapter presents the results of an empirical exploration into current European supply chains. Specific sectoral trends, structural features, strategies, practices and implemented enabling technologies are investigated into cases of excellence that can be considered as a reference point for manufacturing, process and logistics sectors.

The study aims to carry out a holistic and contextualised research to further inform the 10 supply chain strategies identified, i.e. Hyper-Connected Supply Chain (HCSC), Disaster Relief Supply Chain (DRSC), Global Supply Chain (GSC), Urban Supply Chain (USC), Resource Efficient Supply Chain (RESC), Human centred Supply Chain (HSC), Closed Loop Supply Chain (CLSC), Customer Driven Supply Chain (CDSC), Service Driven Supply Chain (SDSC), Biointelligent Supply Chain (BIOSC). A multiple case study (Yin 2013) was performed and guided by the following research questions:

1. How are successful European supply chains shaping the way they produce, distribute and build relationships in their supply network and with customers in order to remain competitive at global level?

2. What practices should be considered to successfully develop one (or more) supply chain strategy among the ones identified as most relevant for the supply chains of the future?

Sectors and industries considered as reference in the European competitive landscape were firstly analysed. Specifically, 8 key industries of European economy were selected, i.e. Automotive, Aerospace, Fashion, Chemical, IT, Distribution/logistics, Furniture, Food and Beverage. These sectors were selected as they demonstrate having large and complex supply chains (in terms of number of echelons and actors involved, and interdependencies with other key European sectors) and unique and complementary features to provide insights into general trends across European and global economy (International Labour Organization 2016). Moreover, they are recognised among more volatile, uncertain, complex and ambiguous (VUCA) operating environments and affected by higher requirements by customers (Roland Berger 2015) and they have been included in the "Internal Market, Industry, Entrepreneurship and SMEs" area of intervention of European Commission. Table 1 summarises the key figures of the 8 industries selected.

Per each sector or industry, one or more case studies were selected in order to obtain a broad overview of the current evolution and successful patterns of practices developed by European supply chains. The 18 companies selected within the 8 industries demonstrate to be sufficiently heterogeneous (Yin 2013) in terms of size, role in the supply chain, and main areas of excellence (i.e. successful practices in different supply chain dimensions). Specifically, the supply chain dimensions considered were the following: Products and services, Sourcing, Production process, Supply chain 
Table 1 Relevant European industries selected in the study

\begin{tabular}{|c|c|c|c|c|}
\hline Industries & Turnover & Workforce & Export & Sources \\
\hline Automotive $^{\mathrm{a}}$ & $\begin{array}{l}€ 1,050 \text { billion } \\
\text { ( } \$ 1174.88 \\
\text { billion) }\end{array}$ & $\begin{array}{l}13.3 \text { million } \\
\text { workers }\end{array}$ & $€ 138.6$ billion & $\begin{array}{l}\text { ACEA }(2018, \\
2019)\end{array}$ \\
\hline Aerospace ${ }^{b}$ & $\begin{array}{l}€ 117 \text { billion } \\
\text { (aero) } € 7.2 \\
\text { billion (space) }\end{array}$ & $\begin{array}{l}540,000 \text { workers } \\
\text { (aero) } 40,000 \\
\text { workers (space) }\end{array}$ & $\begin{array}{l}€ 81 \text { billion } \\
\text { (aero) }\end{array}$ & $\begin{array}{l}\text { AeroSpace and } \\
\text { Defence Industries } \\
\text { Association of } \\
\text { Europe (2018) }\end{array}$ \\
\hline Fashion $^{\mathrm{b}}$ & $\begin{array}{l}€ 181 \text { billion } \\
\text { (textile and } \\
\text { clothing) }\end{array}$ & $\begin{array}{l}1.7 \text { million } \\
\text { workers }\end{array}$ & $\begin{array}{l}€ 141.8 \text { billion } \\
\text { (clothes and } \\
\text { footwear) }\end{array}$ & $\begin{array}{l}\text { Eurostat (2018), } \\
\text { EURATEX (2017) }\end{array}$ \\
\hline Chemical $^{\mathrm{a}}$ & $€ 529.5$ billion & $\begin{array}{l}1.14 \text { million } \\
\text { workers }\end{array}$ & $€ 149.9$ billion & CEFIC (2018) \\
\hline $\mathrm{IT}^{\mathrm{b}}$ & $\begin{array}{l}€ 362 \text { billion } \\
\text { ( } \$ 400 \text { billion) }\end{array}$ & $\begin{array}{l}5.8 \text { million } \\
\text { workers }\end{array}$ & $€ 340$ billion & $\begin{array}{l}\text { Eurostat (2018), } \\
\text { Atomico (2018) }\end{array}$ \\
\hline Distribution/logistics ${ }^{\mathrm{b}}$ & $\begin{array}{l}€ 1,576 \text { billion } \\
\text { (storage and } \\
\text { transport) }\end{array}$ & $\begin{array}{l}10.3 \text { million } \\
\text { workers }\end{array}$ & 1 & Eurostat (2017) \\
\hline Furniture $^{\mathrm{c}}$ & $€ 96$ billion & $\begin{array}{l}1 \text { million } \\
\text { workers }\end{array}$ & $€ 15.1$ billion & EFIC (2019) \\
\hline Food and Beverage ${ }^{c}$ & $€ 1.19$ billion & $\begin{array}{l}4.57 \text { million } \\
\text { workers }\end{array}$ & $€ 110$ billion & $\begin{array}{l}\text { Eurostat (2019), } \\
\text { FoodDrinkEurope } \\
(2019 a)\end{array}$ \\
\hline
\end{tabular}

ain $2018,{ }^{b}$ in $2017,{ }^{c}$ in 2016

configuration (transportation, distribution and warehouse management), Customer relationship. Table 2 presents an overview of the 18 case studies. For reasons of confidentiality the case names have been anonymised and will appear in Italics.

The empirical inquiry involved collection of data from multiple sources, whilst enabling triangulation and reducing possible bias (Yin 2013). Specifically, several publicly available reports and documents were considered for sectoral analysis. The case studies involved semi-structured interviews conducted with key managers (strategic or operational) of supply chain management, operations and logistics areas, and integrated with publicly available data from press reviews, websites and official company documents.

This chapter is structured as follows. Sections 2-9 summarise the main features of each sector in terms of importance, typical supply chain structure (number, type and location of main actors), and main trends characterising the sector dynamics. Dedicated text boxes present briefly the key figures (e.g. turnover and market competitiveness), the structure of the supply chain, and the main practices of the cases selected in each industry.

Section 10 depicts the cross-sectoral analysis, with evidence of commonalities and differences in trends and relevant practices and performance; Sect. 11 presents the results of the cross-case analysis. Specifically, possible matchings were identified 
Table 2 Overview of companies selected in the study

\begin{tabular}{|c|c|c|c|}
\hline Cases & Location (Country) & $\begin{array}{l}\text { Role in the supply } \\
\text { chain }\end{array}$ & Distinctiveness \\
\hline \multicolumn{4}{|l|}{ Automotive } \\
\hline SupplyWheels & Milan (IT) & $\begin{array}{l}\text { First tier supplier of } \\
\text { OEMs (car } \\
\text { manufacturers) }\end{array}$ & $\begin{array}{l}\text { Leader and pioneer in } \\
\text { tailor-made, high segment } \\
\text { car tyres }\end{array}$ \\
\hline AutoSupply & Lippstadt (DE) & $\begin{array}{l}\text { First tier supplier of } \\
\text { OEMs (car } \\
\text { manufacturers) }\end{array}$ & $\begin{array}{l}\text { Worldwide market leader } \\
\text { for climate control and } \\
\text { thermal management for } \\
\text { automotive industry }\end{array}$ \\
\hline \multicolumn{4}{|l|}{ Aerospace } \\
\hline FlyParts.Inc & Alverca (PT) & $\begin{array}{l}\text { First tier supplier of } \\
\text { OEMs (aeronautics } \\
\text { manufacturers) }\end{array}$ & $\begin{array}{l}\text { Long-term, } \\
\text { well-established, global } \\
\text { supply chain focused on } \\
\text { aeronautics } \\
\text { manufacturing and } \\
\text { Maintenance, Repair and } \\
\text { Overhaul (MRO) services }\end{array}$ \\
\hline \multicolumn{4}{|l|}{ Fashion } \\
\hline FashionDesign & Vicenza (IT) & $\begin{array}{l}\text { Designer and } \\
\text { manufacturer }\end{array}$ & $\begin{array}{l}\text { Specialized in R\&D, } \\
\text { engineering and } \\
\text { operations management of } \\
\text { a range of exclusive } \\
\text { fashion brands }\end{array}$ \\
\hline EyewearSupply & Pordenone (IT) & $\begin{array}{l}\text { Manufacturer and } \\
\text { distributor }\end{array}$ & $\begin{array}{l}\text { Leader in the marketing } \\
\text { of ophthalmic and solar } \\
\text { lenses with high level of } \\
\text { personalized services }\end{array}$ \\
\hline FashionOnline & London (UK) & $\begin{array}{l}\text { Distributor and } \\
\text { retailer }\end{array}$ & $\begin{array}{l}\text { Pioneer and world leader } \\
\text { online luxury fashion } \\
\text { retail platform. Ex } \\
\text { unicorn start-up company }\end{array}$ \\
\hline SportShoes & Montebelluna (IT) & $\begin{array}{l}\text { Designer and } \\
\text { manufacturer }\end{array}$ & $\begin{array}{l}\text { Specialization in } \\
\text { personalized sportswear } \\
\text { production }\end{array}$ \\
\hline \multicolumn{4}{|l|}{ Chemical } \\
\hline ChemVariety & Dusseldorf (DE) & $\begin{array}{l}\text { Manufacturer, } \\
\text { distributor, retailer }\end{array}$ & $\begin{array}{l}\text { Multinational company } \\
\text { with leading brands and } \\
\text { technologies in } 3 \text { business } \\
\text { areas: beauty, homecare } \\
\text { and adhesive }\end{array}$ \\
\hline
\end{tabular}


Table 2 (continued)

\begin{tabular}{|c|c|c|c|}
\hline Cases & Location (Country) & $\begin{array}{l}\text { Role in the supply } \\
\text { chain }\end{array}$ & Distinctiveness \\
\hline ConsGoodsLead & Cincinnati (US) & $\begin{array}{l}\text { Manufacturer and } \\
\text { distributor }\end{array}$ & $\begin{array}{l}\text { Multinational corporation } \\
\text { with superior market } \\
\text { performance into several } \\
\text { segments of Fast Moving } \\
\text { Consumer Goods } \\
\text { (FMCG?) }\end{array}$ \\
\hline \multicolumn{4}{|l|}{ IT } \\
\hline LeadTech & $\begin{array}{l}\text { New York (US), } \\
\text { Portsmouth (UK) }\end{array}$ & $\begin{array}{l}\text { Service/technology } \\
\text { provider }\end{array}$ & $\begin{array}{l}\text { Globally-integrated } \\
\text { enterprise leader in the IT } \\
\text { market }\end{array}$ \\
\hline DigitalSCProvider & Walldorf (DE) & $\begin{array}{l}\text { Supply Chain } \\
\text { Software provider }\end{array}$ & $\begin{array}{l}\text { Second global market } \\
\text { leader in the Enterprise } \\
\text { Application Software } \\
\text { (EAS) market }\end{array}$ \\
\hline FinanceTech & Birmingham (UK) & $\begin{array}{l}\text { Service/technology } \\
\text { provider }\end{array}$ & $\begin{array}{l}\text { Supplier finance } \\
\text { technology platform for } \\
\text { both SMEs and banks and } \\
\text { corporates }\end{array}$ \\
\hline \multicolumn{4}{|c|}{ Distribution/logistics } \\
\hline LogisticService & Pedrola (SP) & $\begin{array}{l}\text { Distributor/logistics } \\
\text { operator }\end{array}$ & $\begin{array}{l}\text { Group among the } \\
\text { European logistics } \\
\text { operators with the major } \\
\text { international transport } \\
\text { flows and expansion rate }\end{array}$ \\
\hline
\end{tabular}

Furniture

\begin{tabular}{l|l|l|l}
\hline FurnitureForYou & Delft (NL) & Manufacturer & $\begin{array}{l}\text { Worldwide leader in the } \\
\text { ready-to-assemble, } \\
\text { well-designed and } \\
\text { affordable home furniture }\end{array}$ \\
\hline CarveSupply & Treviso (IT) & First tier supplier & $\begin{array}{l}\text { One of the biggest } \\
\text { manufacturers of furniture } \\
\text { components and kits } \\
\text { worldwide }\end{array}$ \\
\hline Food and Beverage & \multicolumn{5}{|l}{$\begin{array}{l}\text { MealsOnWheels } \\
\text { FoodPrepare }\end{array}$} & Maia (PT) & $\begin{array}{l}\text { Distributor and } \\
\text { retailer }\end{array}$ & $\begin{array}{l}\text { Food retail leader in the } \\
\text { Portuguese market }\end{array}$ \\
\hline PetfoodProducer & $\begin{array}{l}\text { L'Hospitalet de } \\
\text { Llobregat (SP) }\end{array}$ & First tier supplier & $\begin{array}{l}\text { One of the top companies } \\
\text { specialized in food } \\
\text { processing (preparations) }\end{array}$ \\
\hline & Manufacturer & $\begin{array}{l}\text { One of the leading } \\
\text { companies in the } \\
\text { manufacture of animal } \\
\text { food products }\end{array}$ \\
\hline
\end{tabular}


between case studies and supply chain strategies, i.e. which companies (and related supply network) are developing (or are planning to develop) a specific supply chain strategy, or which practices performed by the companies can be linked with the core features of the supply chain strategies identified in Fornasiero et al. (2020).

\section{The Supply Chain of the Automotive Industry}

The Automotive industry is crucial for Europe's prosperity due to its impact on employment and overall economy (contributing to 6.8\% of EU GDP, and generating a trade surplus of $€ 90.3$ billion), and the important multiplier effect in the upstream industries (e.g. steel, chemicals, and textiles), as well as downstream industries (e.g. ICT, repair, and mobility services) (European Commission 2019a).

The main products include: vehicles carrying passengers, vehicles carrying goods, 2- and 3-wheel vehicles and quadricycles (e.g. motorcycles, mopeds, quads, and minicars), agricultural and forestry tractors and their trailers (European Commission 2019a).

The industry is quite fragmented and structured around different tiers, with the leading Original Equipment Manufacturers (OEMs) contracting with a limited number of mainly Tier 1 suppliers for between 4,000 and 9,000 different components contained in a vehicle platform. In the EU, there are 227 automobile assembly and production plants, with a total number of 304 manufacturers in EU27 (ACEA 2018); the number of manufacturers of motor vehicles, trailers and semi-trailers (including various parts and accessories) is 20,161 (Eurostat 2017).

The industry is mainly constituted by mid-sized enterprises. In addition, several EU OEMs (e.g. Renault, BMW and Volkswagen) belong to the worldwide top list of the 2,500 biggest enterprises in Automobiles and Parts (Konrad and Stagl 2018) and have the highest shares of electric powertrain technology patents (Fredriksson et al. 2018).

Nowadays, the industry is shifting to new business models and new technologies (as data-enabled services as alternative powertrains) driven by technological trends as autonomous driving through Artificial Intelligence and connectivity, electrification and shared mobility, in addition to an increasing supply chain sourcing complexity and collaboration due to globalization and sustainability concerns.

\section{CASE STUDY SupplyWheels}

SupplyWheels is a leader and a pioneer in Europe in the production of tailormade car tyres. It is world widely recognised as a premium brand, with a turnover of about $€ 5.2$ billion (2018) and around 31,500 employees. Its supply chain comprises a global supply base, 19 production plants in 12 countries and a commercial presence in over 160 countries, with 15,900 points of sales. 
SupplyWheels is mainly pursuing a Closed Loop supply chain (CLSC) strategy. The company has a very high level of commitment in the environmental, social and economic pillars of sustainability and collaborative mechanisms to reach them. As part of its sourcing strategy, the company has fixed very high and restricted parameters for supplier selection in terms of compliance to high ethical and environmental standards. A supplier handbook has been designed to verify adherence with company principles and values, conduct and managerial approach. In addition, a Supplier Sustainability Audit is regularly commissioned to sector leading companies, and a Supplier Award is assigned each year to suppliers excelling in environmental and social sustainability through technological innovation.

SupplyWheels pursues a Green Sourcing Policy that seeks to promote and incentivise environmental awareness in the overall supply chain, by investing in the tracking, collection, treatment, and transfer into new products for the reuse, recovery and recycle of discarded and end of life tyres.

\section{CASE STUDY AutoSupply}

AutoSupply is one of the world's leading companies in the area of control panels for the Automotive industry, with a turnover of more than $€ 500$ million and over 2,500 employees. It builds partnership-based and long-term cooperation with almost 150 suppliers worldwide and ensures excellent customer service to approximately 30 customers.

AutoSupply is mainly pursuing a Global supply chain (GSC) strategy. The overall supply chain is challenged by global trends as the integration of new technologies and innovative materials in the final products. The partnerships in the upstream supply chain leverage capacity agreements and data exchange for guaranteeing tracking and ensuring safety stocks for delivery (replacement period) and quality problems. The cooperation in the downstream supply chain is supported by the increased adoption of blockchain and mobile apps with global logistic providers to better respond to customer requests.

\section{The Supply Chain of the Aerospace Industry}

The European Aerospace industry contributes to $4.1 \%$ of EU GDP with the development and manufacture of aircrafts, helicopters, drones, aero-engines, other systems 
and equipment. This analysis specifically considers the Civil Aeronautics and Civil Space sub-sectors of Aerospace.

The industry comprises over 3,000 SMEs in Europe, operating in the three main pillars of air framers, engine and equipment manufacturers, and systems manufacturers (AeroSpace and Defence Industries Association of Europe 2018). There are on average three tiers of suppliers providing a broad product line (parts) for the flight vehicles provided to the customers, i.e. airlines companies, states, etc.

The Aerospace supply chain is characterised by a high level of product and supply chain complexity, with large-scale data requirements and the need of extensive expertise for running rate simulation tools and multiple enterprise resource planning systems aimed at ensuring visibility and efficiency along the multi-tier supply chain (Cheater 2017). Companies are then shifting from traditional approaches to new business models and the introduction of digital technologies in all business areas, including digital shop floor, demand sensing, smart procurement and logistics, real-time information sharing platforms, smart products and services (Miller 2018). Aerospace is the largest single industry using additive manufacturing for the production of lightweight parts with complex geometry and small aerostructure components (Roland Berger 2017). Most innovative strategies include risk-andrevenue-sharing business models, also changing the relationship between the OEMs and their suppliers, and the substantial introduction of maintenance services charged by flight-hours and nose-to-tail service in the OEMs' offer.

\section{CASE STUDY FlyParts.Inc}

FlyParts.Inc is one of the leading and oldest aeronautics companies in the world, manufacturing aeronautics parts and providing Maintenance, Repair and Overhaul (MRO) services, with a turnover of $€ 203$ million (2018) and more than 1,900 employees. It has about 70 clients in 40 countries, served by one production plant with 10 maintenance hangars and 1 large engine overhaul shop.

FlyParts.Inc is mainly pursuing a Service-driven supply chain (SDSC) strategy. Well-recognised for experience and reputation, FlyParts.Inc relies on strong relationships with partners, promoting a collaborative supply chain with long-term contracts, a dedicated procurement and inventory management and a strong compliance program with its suppliers. The company is constantly expanding its MRO services portfolio and investing to reduce stocks in maintenance units thanks also to more efficient and faster logistics and transportation. 


\section{The Supply Chain of the Fashion Industry}

The European Fashion industry contributes to the 3\% share of value added and $6 \%$ share of employment on EU manufacturing (European Commission 2015a, b). It is characterised by a tremendous variety of products into several specific subsectors that include Apparel, Textiles, Fabrics, Footwear, Accessories, Watches and Jewellery, Luggage.

There are 176,354 manufacturers of textile and clothing in the EU: the clothing industry has the largest number of companies, estimated 119,343 in 2017 (Statista 2017); the European Footwear sector is represented by 21,000 companies (European Confederation of the Footwear Industry 2018); the European leather industry counts over 3,000 companies (Cotance 2018). European fashion brands are world leaders, and each tier of the production chain is present in Europe (EURATEX 2017). SMEs account for more than $90 \%$ of the workforce and produce almost $60 \%$ of the value added; they are mainly niche players focusing on quality, innovation, creativity and outstanding customer service (EURATEX 2017).

Several trends are disrupting the Fashion industry, including: the decline of brickand-mortar stores and traditional retailers in favour of online platforms and "unified commerce" (i.e. fusing physical and digital stores and integrating activities in a centralised (IT) infrastructure); omnichannel strategies and investments in Directto-Consumer (D2C) sales; the social, environmental and economic responsibility becoming the "new quality"; the moving of major brands towards towards "total look" and "storytelling" (i.e. emotional involvement in the brand, also thanks the involvement of fashion bloggers) to respond to savvy, sophisticated and purposeful consumers (CBI 2016; McKinsey Apparel, Fashion \& Luxury Group 2018).

\section{CASE STUDY FashionDesign}

FashionDesign is the leather goods and footwear division of a fashion group, managing the design and production of all the shoes and bags of the various brands of the group. Specifically, the company has 96 employees and a global turnover of $€ 280$ million in the wholesale/retail channel. The supply chain includes 50 suppliers of raw materials, 60 production plants (contractors) - partly collaborating in product innovation, thanks to adoption of 3D tools for co-design-mainly based in Italy, and worldwide commercial branches.

FashionDesign is mainly pursuing a Global supply chain (GSC) strategy. It is able to combine global trends and Made in Italy into a high level of variety, covering a market positioning of products from the mass-market segment up to the luxury, with an international distribution outreach that changes configuration according to produced products. The use of RFID allows the traceability of the products along the overall supply network, 
avoiding also counterfeiting. The company is committed to transparent and sustainable business practices across the entire group.

\section{CASE STUDY EyewearSupply}

EyewearSupply is an Italian medium enterprise in the eyewear industry producing and marketing finished and semi-finished lenses (and recently also frames), with revenues of $€ 53$ million and more than 100 employees in the only production site. The company daily serves more than 600 wholesalers and optical laboratories across the world and leverages on a total of 40 suppliers worldwide.

EyewearSupply is mainly pursuing a Global supply chain (GSC) strategy. The supply chain is very long and globally distributed, but EyewearSupply relies on collaborative relationships and coordination mechanisms built on trust, mutual economic advantage and technological support (e.g. for coordinated planning of worldwide deliveries) that help in overcoming the informative and cultural gaps with global partners. A trade-off between efficiency and flexibility is reached thanks to a balanced level of automation for both production lines and outbound logistics, the adoption of optimisation models for inventory and transportation loading, and a strategy of stock sharing with customers. This ensures high reliability in terms of service level, dynamicity in adapting to customer requests, and tailored services.

\section{CASE STUDY FashionOnline}

FashionOnline is an English e-commerce business platform in the highluxury Fashion industry, with around 3,200 employees worldwide and revenues of $€ 543.3$ million in 2018. It has established partnerships with a worldwide supply base including 614 world leading luxury retailers and 375 brands, and delivers a large portfolio of luxury fashion items in more than 190 countries.

FashionOnline is mainly pursuing a Hyper-Connected supply chain (HCSC) strategy. It offers a powerful 4PL Supply Chain platform for real-time data sharing, monitoring and tracking from product and content creation to global fulfilment network in integration with its partners.

The company sets up measures for protection of personal data, privacy and information security of final customers. Data are collected from and used by multiple touch points in the luxury fashion ecosystem, and enable relevant personalised services as last mile logistics, better estimate delivery times for 
a seamless buying experience, and tailor marketing and advertising thanks to sophisticated and autonomous Artificial Intelligence and Machine Learning algorithms.

\section{CASE STUDY SportShoes}

SportShoes is an Italian company of the Montebelluna footwear district, specialized in the production of sportswear (especially cycling and snowboarding), with a turnover of around $€ 25$ million in 2017 . The supply chain consists of 20 different suppliers, mainly located in Asia; top-of-the-line items are developed at the Italian headquarter, with selected materials exclusively from artisanal "Made in Italy" processes. The downstream network is divided into a direct (Italy and Germany) and an indirect market, with 102 distribution companies worldwide.

SportShoes is mainly pursuing a Customer Driven supply chain (CDSC) strategy. Products are mainly customised based on specific requirements of customers, with development of ad hoc prototypes of new models of shoes and clothing with 3D printing systems, and all the decisions regarding sourcing and production are determined by a production model completely driven by consumer's demand and needs. The customer experience starts from the selection of materials to the personalised distribution and the aftersale services that guarantee the replacement/repair of products during the use by customers.

\section{The Supply Chain of the Chemical Industry}

The European Chemical industry is among the most consolidated and accounts for $1.1 \%$ share of value added and $7.3 \%$ share of employment on EU manufacturing (Eurostat 2019).

Chemical products are used in making $95 \%$ of all goods, and they can be subdivided in three main categories: base chemicals (petrochemicals; polymers, and basic inorganic), specialty chemicals (including agricultural chemicals) and consumer chemicals.

Europe is the 2nd largest chemicals producer in the world, with a share of $15.6 \%$ in total sales. Although the majority of supply chain activities are on global level, the EU Member States account for 50\% of global chemicals trade, with $30 \%$ of exports going to non-EU countries. The number of European chemicals manufacturers in the EU is 28,329, with $95 \%$ of them employing fewer than 250 staff members (CEFIC 2017). 
Main supply chain actors are substance producers and formulators of preparations, industrial chemical users, distributors. In Europe, the main factors affecting the competitiveness of the chemical industry are the energy costs, the EU regulation costs, the levelled consumption due to the end markets' trends, the merging and acquisition resulting in the creation of giant companies, the shift of chemicals manufacturing to Asia, the introduction of technologies such as real-time analytics and automated control actions towards Chemicals 4.0 (CEFIC 2018).

\section{CASE STUDY Chem Variety}

ChemVariety is a German company from the Chemical industry with an international outreach in three different sectors corresponding to the Business Units (BU) of beauty, laundry and home care, adhesive technologies. It has more than 53,000 employees and a turnover of more than $€ 20$ million for 2018. The supply chain is centralised geographically, with the sourcing process fully leveraged across BUs, but the production activities in the more than 180 production plants are contextualised according to geographic, economic and political features.

ChemVariety is mainly pursuing a Global supply chain (GSC) strategy. The scale-up of technological solutions across functions, regions and BUs allows to optimize both costs and fulfilment of local needs. The company leverages a common IT system for real time monitoring, tracking and traceability along the supply chain; a common Industry 4.0 strategy to integrate IoT, automation, robotics, analytics and related training in the production, and nearfield technologies and drones in logistics; data collection through different channels, as platforms and social media, to better understand needs and issues of the final customers across BUs. All the plants are pursuing sustainability with reduction of emissions, water use and waste volumes, and adoption of recycled materials packaging.

\section{CASE STUDY ConsGoodsLead}

ConsGoodsLead is one of the world's largest consumer goods companies, with more than 92,000 employees worldwide and reported revenues of more than $\$ 66.8$ million in 2018 . The globally distributed supply chain comprises more than 100 suppliers and has a commercial presence in over 180 countries.

ConsGoodsLead is mainly pursuing a Resource Efficient supply chain (RESC) strategy. The supply chain is organised to realise scale advantages across the several business operations by the adoption of co-location strategy with suppliers (manufacturing operations closed to raw materials), and a 
data-driven approach for sourcing strategy. The distribution network leverages a centralised data platform for warehouses and transportation management, which comprises the co-loading with competitors and cost-sharing for customer shipments. This helps to optimise trucks vehicles fill/loading rates by also using inter-modal and multi-modal logistics agreements. In addition, a common supply chain finance system allows to gain operational synergies.

ConsGoodsLead shares along the overall supply chain science-based sustainability targets for reducing impacts and accordingly lean-and-green practices.

\section{The Supply Chain of the IT Industry}

The European IT industry contributes to the $4.8 \%$ of the European economy and has grown $500 \%$ in the last five years as economies, jobs and personal lives are becoming more digital, connected and automated, with an estimated grow at a rate of 5\% (Certification Europe 2019).

The IT industry comprises companies that produce software, hardware, semiconductor equipment and companies that provide internet and related services such as Google, Apple, Facebook, Cisco, IBM and Intel (ITI 2019; CompTIA 2019), including blockchain and security. The IT supply chain has among the most complex structures, especially due to the high degree of outsourcing of activities to design firms, consultancy firms and contract manufacturers.

There are 17 European tech companies that surpassed the over $\$ 1$ billion milestone in 2018, and Europe is now consistently producing companies exceeding \$5 billion in value, also thanks to the presence of more than 180 tech hubs across the territory (Atomico 2018).

Main trends affecting the industry, resulting in increasing investments in capabilities and security, include: the emerging tech categories, the need to be compliant with security regulation (e.g. European Union's General Data Protection Regulation (GDPR)), the cybersecurity, the shifting to strategic IT alongside business units (CompTIA 2019; Deloitte 2019).

\section{CASE STUDY LeadTech}

LeadTech is a global leader in the information technology market, providing software, innovative technologies and consulting solutions, with a turnover 
of about $\$ 80$ billion in 2018 and around 360,000 employees. It has a global presence and operates in more than 175 countries.

LeadTech is mainly pursuing a Customer Driven supply chain (CDSC) strategy. LeadTech provides consultancy and innovative technologies and creates solutions targeted on the needs of their clients and also co-created with them. It supports the customers in learning to control relationships across the supply chain and gaining knowledge about the whole supply chain through information exchange point-to-point to achieve agility, reduce costs and risks, modernise their operations, innovate and achieve a secure infrastructure. Specifically, it focuses on the implementation of blockchain technology in achieving increased collaboration and visibility across the supply chain.

\section{CASE STUDY DigitalSCProvider}

DigitalSCProvider is a provider of enterprise application software headquartered in Germany, with worldwide revenues of $€ 24.7$ million. It leverages on a network comprising of more than 13,000 partners to provide end-to-end, industry-specific solutions to 25 industries and 12 business lines.

DigitalSCProvider is mainly pursuing a Human centred supply chain (HSC) strategy. The company grounds its vision on the concept of 'intelligent enterprise' and 'augmented human intelligence' guiding the overall supply chain strategy of its customers. Specifically, it supports the development of IoT in manufacturing operations, inter-robot orchestration and machine-to-machine feedback systems to increase the visibility of manufacturing operations, integrated with the attention towards understanding the impacts of digitalization on workers' capabilities, employment and changes in educational models for enhancing better working environments.

\section{CASE STUDY FinanceTech}

FinanceTech is a software company that provides and operates a finance technology platform for supplier early payments solutions, with targeted invoice finance solutions. It is a small company with a turnover of $£ 12.3$ million in 2018, mainly deriving from the public sector. It sits in the middle of three different actors, i.e. buyers, suppliers and investors, to provide an innovative invoice financing model for supply chain value. 
FinanceTech is mainly pursuing a Service Driven supply chain (SDSC) strategy. The developed technology enhances avoiding risks and problems along the supply chain as limited cash flows and late invoice payments with targeted invoice finance solutions. The company keeps innovating the platform with cross border and cross currency supply chain flows in order to grow the offered services across multiple countries and currencies.

\section{The Supply Chain of the Distribution/Logistics Industry}

The European Distribution/logistics industry is rapidly developing and one of the largest in the EU, with 10.3 million workers (Eurostat 2017) and a share of $9.7 \%$ on the GDP. The main services include internal transport (from arrival to the warehouse or from final assembly to shipping), external transport (between two sites or from supplier to customer), warehousing, packaging, value added services (such as custom packaging, assembly or data management and information management).

The number of transport and storage enterprises in the EU 2017 is 1,246,259 (Eurostat 2017). They are mainly SMEs, with an aggregate of 9.1 employees and mainly focused on road transport, while the bigger enterprises offer railway, air, sea and road transport (European Commission 2015a, b).

Main trends shaping the European logistics industry are: the shifts in international trades due to free trade agreements or trade wars; the process changes driven by the introduction of automation, robotics, Artificial Intelligence, Internet of Things (IoT) and Blockchain; the development of innovative last-mile delivery by using autonomous drones and vehicles; the electric mobility advancements and transport machine technology developments (DHL 2018; PwC 2019).

\section{CASE STUDY LogisticService}

LogisticService is a logistics operator delivering supply, transport, storage, and distribution services, with a group-level turnover of almost $€ 160$ million and a total of 1,100 employees. Its supply chain comprises more than 800 suppliers of transport fleets and a total of 7 warehouses.

LogisticService is mainly pursuing a Service Driven supply chain (SDSC) strategy. The company guarantees the full traceability of service as key objective to be accomplished in integration with the customers' tools and adopts advanced data analytics (i.e. positioning and utilisation of the entire fleet) for supporting decision-making in service delivery and enhancing customer competitiveness. LogisticService has established collaborative relationships with its customers, working together in projects to optimise 
routes and decision-making based on business intelligence and the adoption of apps to control the supply chain, and recently introducing last mile distribution and multimodal transportation to answer their requests.

\section{The Supply Chain of the Furniture Industry}

The European Furniture industry is labour-intensive and highly export-oriented, especially inside Europe. It employs around 1 million workers in 130,000 companies, most of them SMEs and micro firms (EFIC 2019).

The main products include household (domestic) furniture, office and institutional furniture, furniture related products and other semi-finished and component products.

The European Furniture supply chain is spread in all the territory and consists of four major components: suppliers, manufactures/producers, retailers and consumers. It can be configured by destination (office furniture, kitchen and bathroom furniture, dining, living and bedroom furniture), by components type (bars, cabinet doors, drawers, frames, worktops, others), by support material (wood, MDF, particle board, plywood, other materials), by wood species, and by coating material (veneer, melamine foils, laminates, PVC, lacquered) (Worldforniture 2019). All supply chain tiers are characterised by a high number of SMEs and the participation of some big players (highlighting IKEA, the world's largest furniture retailer).

The European Furniture sector has undergone significant changes after the worldwide crisis and important trends as: eco-design to reduce energy consumption and plan the entire products' life-cycle (including transportation) in line with the principles of the circular economy; the requests for more affordable furniture options, due to the increasing renting, and a higher diversification to address the different lifestyles and needs of customers; fast changes in design trends requiring continuous investments in innovation (CMTC 2019).

\section{CASE STUDY FurnitureForYou}

FurnitureForYou is a Swedish company leading the home furniture retailing industry, with a turnover of $€ 38.8$ billion in 2018 and a number of employees (defined co-workers) that is 208,000 worldwide (20,000 of them in production units). The company has 1,500 suppliers worldwide and more than 400 stores in 50 markets.

FurnitureForYou is mainly pursuing a Human centred supply chain (HSC) strategy. The company pay particular attention to the human factor along the supply chain. In fact, the most important KPI for the purchase agreements, fixed also in the Code of Conduct, is the safety of workers (e.g. considering the loss-time frequency due to accidents). Within production plants, beyond the investments on automatic guided vehicles and robots, the company 
has a strong attention towards the importance of the "soft" and human part in the change required for digital transformation (and its impacts), nurturing internal talents for reaching agility and cross-functional empowerment of workers. In the stores, operators (and customers) are supported with augmented reality tools and embedded digital touch points.

\section{CASE STUDY CarveSupply}

CarveSupply is one of the biggest manufacturers of components and kits for the furniture industry worldwide, with around 2000 employees and a turnover of $€ 550$ million in 2018. Its supply chain includes almost 230 suppliers worldwide and a huge logistics volume to serve the main international large-scale retail chains.

CarveSupply is mainly pursuing a Hyper-Connected supply chain (HCSC) strategy. The company shows a very high level of integration, leveraging on trust and transparency at logistic, informative and organisational level with both upstream and downstream supply chain, from the co-design of new products, processes and dedicated production technologies to the full traceability of the products along the logistics flows, including the packaging.

The more advanced production lines are fully automated, with collaborative robotics and a Data Exchange framework for machine-to-machine integration. While automated vehicles are adopted for internal logistics, the company is shifting to an intermodal transportation system to further consolidate/integrate the activities with the suppliers worldwide.

\section{The Supply Chain of the Food and Beverage Industry}

The Food and Beverage industry is the EU's biggest manufacturing sector in terms of value added, with a share of $12.1 \%$ (European Commission 2019b) and job creation, employing more than 23 million people (Eurostat 2019; FoodDrinkEurope 2019a). In half of the EU's 28 Member States, the Food and Beverage industry is the biggest employer within manufacturing (FoodDrinkEurope 2019a).

The main products of the sector in Europe are meat products, dairy products, processed fruit and vegetables, oils and fats, bakery and farinaceous products, animal feeds, fish products, grain mill and starch products, drinks (alcoholic and nonalcoholic) (FoodDrinkEurope 2019a). The supply chain comprises companies that process, pack and distribute edible goods, including fresh, prepared and packaged foods, as well as alcoholic and non-alcoholic beverages. It is characterised by a huge 
number of SMEs (99\%) across all tiers from farms to retails and restaurants, and the participation of big players that embrace all European territory (and beyond) and respond for more than $50 \%$ of the turnover.

Driven by demographic and environmental changes that impact on food needs and connected lifestyles, main trends characterising the European Food and Beverage industry are: production and exploitation of alternative and sustainable food sources for more healthy and sustainable diets; new distribution models, such as direct to consumer distribution; adoption of IoT-connected packaging and other digital technologies as sensors and Artificial Intelligence for flexible, customized and energyefficient infrastructures and processes; increasing offer of specific and personalized products as gluten-free ones (CB Insights 2018; FoodDrinkEurope 2019b).

\section{CASE STUDY MealsOnWheels}

MealsOnWheels is a Portuguese omnichannel food retailer, with more than 30,000 employees and a turnover of $€ 4.3$ billion in 2018. The supply chain comprises between 700 and 800 suppliers, mainly based in Portugal, and a total of 1,116 stores selling a large variety of products with the company's or the suppliers' brands.

MealsOnWheels is mainly pursuing an Urban supply chain (USC) strategy. Building on a centralised transportation and warehousing network and solid long-term procurement relationships, the company is adapting the logistics to the city with small-sized and last-mile deliveries. This is supported by the use of location technologies for real-time control, the implementation of simulation and optimisation techniques for routes and cargo space of transporting vehicles, and the adoption of different store size strategies targeted to local needs.

To reduce food waste, MealsOnWheels works with partners to address circularity and diversify the portfolio according to the local city needs, by transforming perishables that are not sold on a given period (but still deemed good for consuming) into other products sold by the same company, and also by collecting empty plastic packaging.

\section{CASE STUDY FoodPrepare}

FoodPrepare is a global group of companies focused on the design, development and supply of added value ingredients for the Food and Beverage industry, achieving a turnover of $€ 110$ million in 2018 and around 530 employees. The globally distributed supply chain includes between 400 and 500 suppliers, 8 production plants and almost 100 clients.

FoodPrepare is mainly pursuing a Customer Driven supply chain (CDSC) strategy. The company constantly invests in innovative capabilities and 
big data analytics to capture and follow the trends of the final market to produce new products and ensure high quality, on-time, flexible delivery of manufactured products for customers. Both procurement and delivery models are entirely demand-driven and optimised thanks to the adoption of digital platforms integrating the information flows with suppliers and business customers. The entire production process is digitalised and agile manufacturing enhances switches and implementation of new or different machinery and production lines according to on-time data of product characteristics. Part of the production units are close to clients, with make-to-order shipping of finished food preparations and using last-mile delivery.

\section{CASE STUDY PetfoodProducer}

PetfoodProducer is a multinational company of the feed animal sector, with a turnover of $€ 620$ million in 2018 and more than 1,800 employees. It has around 20,000 customers in Europe and a total of 7 production plants.

PetfoodProducer is mainly pursuing a Resource Efficient supply chain (RESC) strategy. The company has introduced IoT technologies to collect data, monitor the processes and stock points, and measure the footprint and wastes, both in transport and storage. It continuously re-designs its logistics network in order to optimise routes and ensure a total visibility and traceability along the supply chain with the use of a cloud based platform. Moreover, it is actively working on collaborative projects with several manufacturers to share transportation means and improve efficiency of loadings.

\section{Cross-Sectoral Analysis: Main Trends and Practices}

The main features and dimensions of interest of the analysed industries can be summarised as follows.

This study included both very big and top-employer industries, as the Automotive (13.3 million workers) and Distribution/logistics (10.3 million workers), and smaller ones as the Aerospace (580,000 workers). Differences in numbers are also justified by the presence of big players, as for the IT sector that includes 17 companies surpassing 1 billion of revenues and has a Gross Value Added growing five times faster than the rest of the European economy.

From the one side, all included industries are characterised by a high number of SMEs, reaching a significant percentage in Food (99\% of total companies), Fashion 
$(99 \%)$ and Chemical (95\%) industries. From the other side, many of the top players of the sector are worldwide leaders, as in the case of the Fashion and Chemical sectors.

The cross-sectorial analysis reveals also commonalities in trends and practices characterising the 8 industries. Common trends can be summarised as:

- digitalization/adoption of enabling technologies: e.g. in Automotive industry with electric vehicles and autonomous driving through Artificial Intelligence, and in Chemical industry with real-time analytics and automated control for energy efficiency;

- new business models: driven by technological advancements and/or integration of value offer, e.g. in Aerospace industry with new risk-and-revenue-sharing (between suppliers and OEMs) business models, and in Food and Beverage industry with increasing sustainable and healthy diets and climate smart and environmentally sustainable food systems;

- new roles and structure of the supply chain: e.g. in Aerospace industry with the increasing building of alternative supplier networks through multiple sourcing, and in Furniture industry with the reorganization of the supply chain for realizing custom elements and multifunctional pieces.

Another cross-sectorial analysis concerns the relevant practices and performance, which can be classified according to main supply chain dimensions considered in the case study analysis, including the one of sustainability. Specifically, as regards production process, companies belonging to different industries adopt increasing quality and safety standards and control in production and lean principles, while there are different tendencies to outsource (e.g. Aerospace), nearshoring (e.g. Fashion) and increasing partnerships (e.g. IT). In both sourcing and supply chain configuration main efforts of companies in different industries are addressed towards better synchronization, cost efficiency, flexibility and security. There are also opposite tendencies towards vertical integration (as in Fashion industry) or high levels of outsourcing (e.g. Distribution/logistics). Different practices are adopted in the customer relationship, regarding the inclusion into the value offer of customized products (e.g. Chemical) or with an increasing level of integrated services (e.g. Aerospace), or the need for innovation and transparency in marketplaces (e.g. Distribution/logistics).

Finally, as regards sustainability, we can argue that companies in the majority of industries aim to reduce environmental impacts (e.g. reduction of emissions and use of renewable/alternative energy sources) and identify solutions for adaptable, resilient and compliant supply chains. 


\section{Cross-Case Analysis: Supply Chain Strategies and Best Practices}

This section provides an overview of the main features, commonalities and differences among the cases included in this study.

Focusing on company dimension, the results of the analysis show a majority of big companies (13 out of 18), as the main objective is to collect best practices from important players of European supply chains, but also SMEs (a total of 5) have been included as they constitute a significant percentage in many of the selected sectors. Focusing on the role in the supply chain, the selected companies belongs to both upstream and downstream supply chain, with a majority of first tier suppliers (5 out of 18) and focal companies (2 manufacturers and 3 acting both as main manufacturer and distributor), followed by service/technology provider (4 out of 18). This allows the analysis to be more comprehensive in capturing different perspectives on good and best practices for the whole supply chain.

The results also reveal that each company carries out one or a combination of the 10 supply chain strategies identified in Fornasiero et al. (2020), identifying different matchings between cases and strategies that are summarized in Table 3.

The majority of companies show the features of (or the willingness to develop) a Global supply chain (10 out of 18) or Hyper-connected supply chain (7 out of 18). This is in line with the key trends characterising all industries, i.e. globalisation and digitalisation (and enhanced connectivity). The third most adopted supply chain strategy is Resource efficient, revealing a key priority of pursuing efficiency along all supply chain dimensions. Finally, Service-driven supply chain (5 cases out of 18) and Customer-driven supply chain (4 cases out of 18) show the tendency to shape the supply chain according to the value offer, respectively integrating services and in terms of strict response to customers' requirements.

None of the cases seem to implement (or show the willingness to develop features of) the Bio-intelligent supply chain and Disaster-relief supply chain, but both strategies are more "futuristic" with higher requirements in terms of collaboration and technological development than the other supply chain strategies. Only one company is developing Urban manufacturing supply chain (MealsOnWheels), which is mainly linked to the concept of smart city, and adopts only some practices for urban logistics (e.g. last mile delivery) but not manufacturing. Also Closed-loop supply chain is adopted by one company (SupplyWheels) as it is quite difficult to implement full circularity beyond sustainability in the overall supply chain.

Finally, Table 4 summarizes the results of the cross-case analysis of the supply chain strategies described in the section above, and the practices/key points highlighted in each supply chain dimension (Products and services, Sourcing, Production process, Supply chain configuration, Customer relationship). Strategies that are mainly affected by practices identified in the cross-case analysis are also highlighted. Part of these practices were summarized in the single boxes of this section.

As the number of companies differ among the 10 supply chain strategies, the identified practices can not be attributed uniquely and incontrovertibly to a single or more 


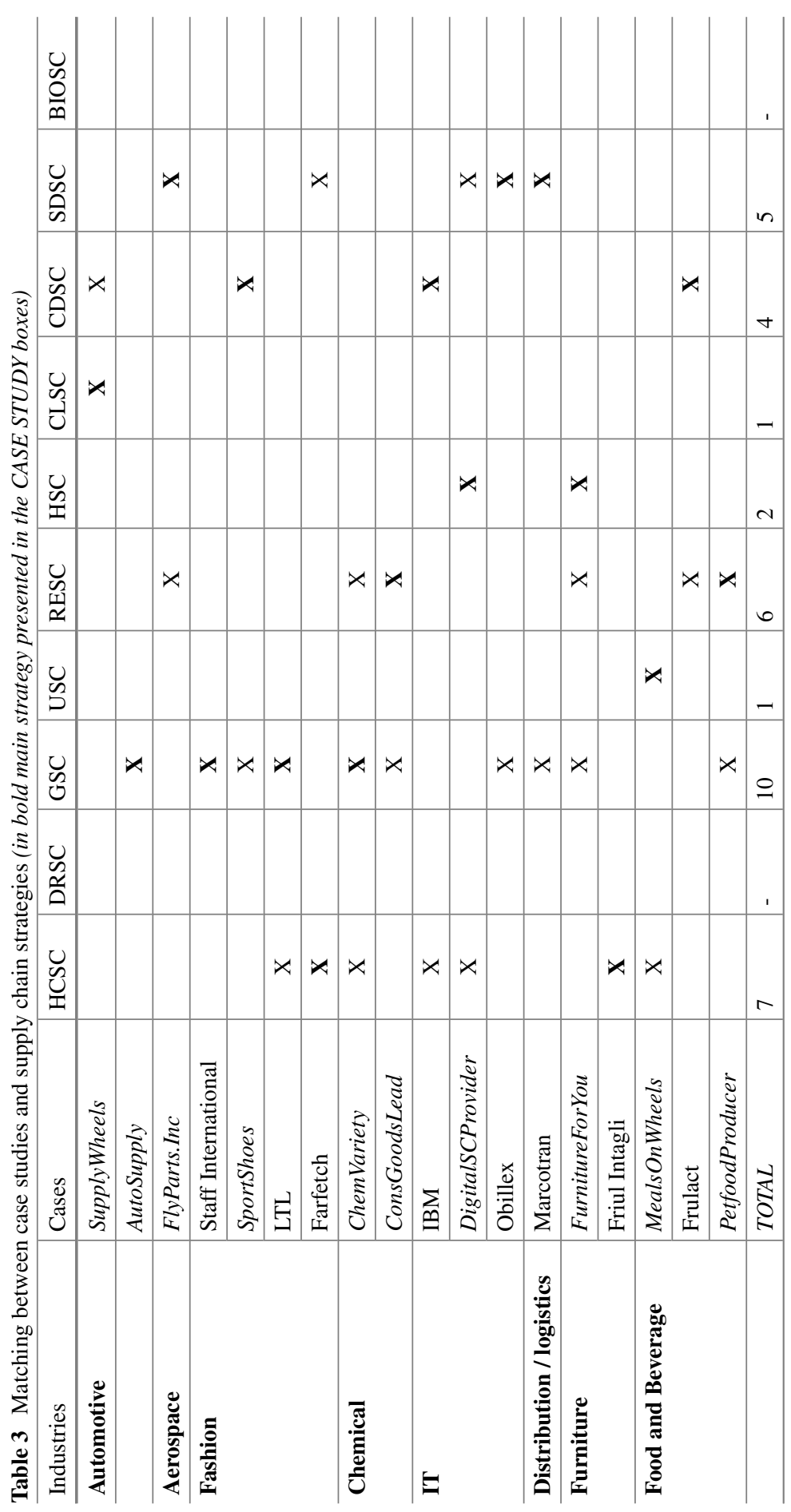


Table 4 Key practices of case studies and strategies per each supply chain dimension

\begin{tabular}{|c|c|c|}
\hline Key practices & Examples of practices from cases & Supply chain strategies \\
\hline \multicolumn{3}{|l|}{ Products and services } \\
\hline $\begin{array}{l}\text { Defining products and services } \\
\text { portfolio }\end{array}$ & $\begin{array}{l}\text { - High diversity / wide assortment } \\
\text { in product / service portfolio } \\
\text { - On-demand / tailor-made / } \\
\text { customer-specific solutions }\end{array}$ & $\begin{array}{l}\text { HCSC } \\
\text { GSC } \\
\text { USC } \\
\text { CDSC } \\
\text { SDSC }\end{array}$ \\
\hline $\begin{array}{l}\text { Outlining value chain and } \\
\text { strategy }\end{array}$ & $\begin{array}{l}\text { - Focus on single product segment } \\
\text { - Strategies and supply chain } \\
\text { management targeted to specific } \\
\text { products or markets }\end{array}$ & $\begin{array}{l}\text { GSC } \\
\text { RESC } \\
\text { CDSC } \\
\text { SDSC }\end{array}$ \\
\hline $\begin{array}{l}\text { Digitalization in products and } \\
\text { services }\end{array}$ & $\begin{array}{l}\text { Introduction of new technologies } \\
\text { or new materials }->\text { smart products } \\
\text { or services }\end{array}$ & $\begin{array}{l}\text { HCSC } \\
\text { GSC } \\
\text { CLSC } \\
\text { CDSC } \\
\text { SDSC }\end{array}$ \\
\hline $\begin{array}{l}\text { Sustainability in products and } \\
\text { services }\end{array}$ & $\begin{array}{l}\text { Products/services environmentally } \\
\text { sustainable / aimed at circular } \\
\text { economy }\end{array}$ & $\begin{array}{l}\text { HCSC } \\
\text { RESC } \\
\text { USC }\end{array}$ \\
\hline $\begin{array}{l}\text { Processes supporting products } \\
\text { and services development }\end{array}$ & $\begin{array}{l}\text { - Scan of global trends and } \\
\text { customer behaviors } \\
\text { - Continuous investments in R\&D } \\
\text { (product, service and process } \\
\text { innovation and related } \\
\text { capabilities) }\end{array}$ & $\begin{array}{l}\text { HCSC } \\
\text { GSC } \\
\text { RESC } \\
\text { CDSC } \\
\text { SDSC }\end{array}$ \\
\hline \multicolumn{3}{|l|}{ Sourcing } \\
\hline Supplier selection and evaluation & $\begin{array}{l}\text { Supplier rating and selection based } \\
\text { on trade-off among several KPIs }\end{array}$ & $\begin{array}{l}\text { HCSC } \\
\text { GSC } \\
\text { SDSC }\end{array}$ \\
\hline $\begin{array}{l}\text { Defining kind of relationship with } \\
\text { suppliers }\end{array}$ & $\begin{array}{l}\text { - Different kinds of relationship } \\
\text { with suppliers / multiple } \\
\text { sourcing strategies } \\
\text { - Long-term partnerships / } \\
\text { established contracts with } \\
\text { suppliers } \\
\text { - Co-creation of product (or parts) } \\
\text { with suppliers } \\
\text { - Vertical integration: ownership } \\
\text { of suppliers' plants or } \\
\text { co-location with them }\end{array}$ & $\begin{array}{l}\text { HCSC } \\
\text { GSC } \\
\text { RESC } \\
\text { USC } \\
\text { CDSC } \\
\text { SDSC }\end{array}$ \\
\hline Digitalization in sourcing & $\begin{array}{l}\text { Real-time data sharing, monitoring } \\
\text { and tracking for supporting } \\
\text { integration in purchasing }\end{array}$ & $\begin{array}{l}\text { HCSC } \\
\text { GSC } \\
\text { RESC } \\
\text { USC } \\
\text { CDSC } \\
\text { SDSC }\end{array}$ \\
\hline
\end{tabular}


Table 4 (continued)

\begin{tabular}{l|l|l}
\hline Key practices & Examples of practices from cases & Supply chain strategies \\
\hline $\begin{array}{l}\text { Cultivating relationships with } \\
\text { suppliers according to specific }\end{array}$ & - Strict supplier audit / compliance & HCSC \\
priority areas & to regulations (e.g. & GSC \\
& sustainability)/ certifications & RESC \\
& (e.g. industry-specific) & CLSC \\
& Supplier award & HSC \\
& & CDSC \\
\hline
\end{tabular}

\section{Production process}

\begin{tabular}{|c|c|c|}
\hline Design of production lines & $\begin{array}{l}\text { - Co-development of production } \\
\text { technologies with providers } \\
\text { - Full customization of production } \\
\text { lines for product category }\end{array}$ & $\begin{array}{l}\text { HCSC } \\
\text { GSC } \\
\text { RESC } \\
\text { CDS }\end{array}$ \\
\hline $\begin{array}{l}\text { Digitalization in production } \\
\text { processes }\end{array}$ & $\begin{array}{l}\text { - (Full) automation of production } \\
\text { lines } \\
\text { - Automation limited to some } \\
\text { production lines / phases } \\
\text { - Real time data exchange between } \\
\text { machines and informative } \\
\text { systems to monitor the shop floor } \\
\text { - Partially digitalized data } \\
\text { collection from shop floor for } \\
\text { monitoring }\end{array}$ & $\begin{array}{l}\text { HCSC } \\
\text { GSC } \\
\text { RESC }\end{array}$ \\
\hline $\begin{array}{l}\text { Sustainability and efficiency in } \\
\text { production processes }\end{array}$ & $\begin{array}{l}\text { - Sustainability practices in } \\
\text { production (wastes, renewable } \\
\text { energies) } \\
\text { - Lean manufacturing / } \\
\text { just-in-time }\end{array}$ & $\begin{array}{l}\text { GSC } \\
\text { RESC } \\
\text { CDSC }\end{array}$ \\
\hline $\begin{array}{l}\text { Cultivating excellence in } \\
\text { operations according to specific } \\
\text { priority areas }\end{array}$ & $\begin{array}{l}\text { - Investments in both training and } \\
\text { technologies for operational } \\
\text { excellence } \\
\text { - Integration of production and } \\
\text { logistics operations for scale } \\
\text { advantages } \\
\text { - Pursuing trade-off between } \\
\text { flexibility and full-capacity } \\
\text { utilization }\end{array}$ & $\begin{array}{l}\text { HCSC } \\
\text { GSC } \\
\text { RESC } \\
\text { HSC } \\
\text { CDSC }\end{array}$ \\
\hline
\end{tabular}

\section{Supply chain configuration}

Defining relationship with
distributors / logistics providers

Long-term relationships with
wholesalers and / or transportation
companies

GSC

RESC

CLSC

USC

CDSC 
Table 4 (continued)

\begin{tabular}{|c|c|c|}
\hline Key practices & Examples of practices from cases & Supply chain strategies \\
\hline $\begin{array}{l}\text { Digitalization in supply chain } \\
\text { configuration }\end{array}$ & $\begin{array}{l}\text { - Automation of warehouses } \\
\text { logistics and internal } \\
\text { transportation } \\
\text { - Integration (informative / digital } \\
\text { management systems) for } \\
\text { real-time data sharing in } \\
\text { outbound logistics } \\
\text { - Integration (informative / digital } \\
\text { management systems) for } \\
\text { real-time data sharing in both } \\
\text { inbound and outbound logistics }\end{array}$ & $\begin{array}{l}\text { HCSC } \\
\text { GSC } \\
\text { CLSC } \\
\text { USC } \\
\text { CDSC } \\
\text { SDSC }\end{array}$ \\
\hline $\begin{array}{l}\text { Sustainability in supply chain } \\
\text { configuration }\end{array}$ & $\begin{array}{l}\text { Circularity, sustainability and } \\
\text { environmental-aware practices in } \\
\text { logistics (include reverse logistics, } \\
\text { packaging, transportation and } \\
\text { collaboration) }\end{array}$ & $\begin{array}{l}\text { HCSC } \\
\text { GSC } \\
\text { RESC } \\
\text { CDSC }\end{array}$ \\
\hline $\begin{array}{l}\text { Processes supporting } \\
\text { transportation management }\end{array}$ & $\begin{array}{l}\text { - Optimization of transportation } \\
\text { (e.g. trucks loading, last mile } \\
\text { delivery) } \\
\text { - Intermodality for outbound } \\
\text { logistics }\end{array}$ & $\begin{array}{l}\text { HCSC } \\
\text { GSC } \\
\text { RESC } \\
\text { USC } \\
\text { CDSC }\end{array}$ \\
\hline $\begin{array}{l}\text { Processes supporting } \\
\text { warehouses management }\end{array}$ & $\begin{array}{l}\text { - Optimization and reduction of } \\
\text { stocks, considering buffers } \\
\text { - Integration of processes } \\
\text { (warehouses management and } \\
\text { distribution) }\end{array}$ & $\begin{array}{l}\text { HCSC } \\
\text { GSC } \\
\text { RESC } \\
\text { SDSC }\end{array}$ \\
\hline $\begin{array}{l}\text { Targeting downstream supply } \\
\text { chain configuration according to } \\
\text { specific priority areas }\end{array}$ & $\begin{array}{l}\text { - Multi-modality in outbound } \\
\text { logistics for last mile delivery } \\
\text { - Centralized supply chain finance } \\
\text { system } \\
\text { - Continuous replenishment based } \\
\text { on product category }\end{array}$ & $\begin{array}{l}\text { GSC } \\
\text { RESC } \\
\text { USC } \\
\text { CSCS } \\
\text { SDSC }\end{array}$ \\
\hline
\end{tabular}

\section{Customer relationship}

\begin{tabular}{l|l|l}
\hline $\begin{array}{l}\text { Defining kind of relationship with } \\
\text { customers }\end{array}$ & $\begin{array}{l}\text { Long-term customer } \\
\text { relationships }\end{array}$ & HCSC \\
& - Co-creation of products / & GSC \\
& RESC \\
& cervices / solutions with & CLSC \\
& - Collaboration in design and \\
production of technological and & CDSC \\
& logistics processes and systems \\
with customers & \\
& SDSC \\
\hline $\begin{array}{l}\text { Cultivating relationships with } \\
\text { customers according to supply } \\
\text { chain strategy }\end{array}$ & $\begin{array}{l}\text { Agreements on IPR management } \\
\text { Ensure level of service, } \\
\text { dynamicity, flexibility, direct }\end{array}$ & HCSC \\
& GSC \\
& RESC \\
& requests in adapting to customer & USC \\
& & HSC \\
& SDSC \\
\hline
\end{tabular}


Table 4 (continued)

\begin{tabular}{|c|c|c|}
\hline Key practices & Examples of practices from cases & Supply chain strategies \\
\hline $\begin{array}{l}\text { Digitalization in customer } \\
\text { relationship }\end{array}$ & $\begin{array}{l}\text { - Ensuring visibility on process } \\
\text { advancements to customers } \\
\text { - Downstream integration for } \\
\text { information sharing/integration } \\
\text { of processes with customers } \\
\text { - Investments in Digital } \\
\text { Marketing/Customer } \\
\text { experience/journey }\end{array}$ & $\begin{array}{l}\text { HCSC } \\
\text { GSC } \\
\text { RESC } \\
\text { CLSC } \\
\text { CDSC }\end{array}$ \\
\hline $\begin{array}{l}\text { Processes supporting demand } \\
\text { planning and forecasting and } \\
\text { marketing }\end{array}$ & $\begin{array}{l}\text { - Data collection and analysis } \\
\text { through different means to target } \\
\text { marketing and better planning } \\
\text { and forecasting } \\
\text { - Multi-/omni-channel selling and } \\
\text { marketing strategy }\end{array}$ & $\begin{array}{l}\text { GSC } \\
\text { RESC } \\
\text { CDSC } \\
\text { SDSC }\end{array}$ \\
\hline
\end{tabular}

strategies. The same practice can be applied with a different scope according to the supply chain strategy which is aimed to be realized. For example, the real-time data sharing, monitoring and tracking for supporting integration in purchasing (under the macro-practice of digitalization in sourcing) is performed by companies addressing a strategy of: Hyper-connected supply chain (e.g. CarveSupply, with a significant level of trust and transparency to ensure real time sharing of data on warehouses and deliveries), Global supply chain (e.g. AutoSupply, with tracking aimed at supporting the strategy of multiple sourcing and safety stocks), Urban supply chain (e.g. MealsOnWheels, which fixes very high and restricted parameters in supplier selection in order to guarantee a purchasing process of excellence, guaranteeing continuity and full capacity utilization in the urban-level downstream supply chain), Customerdriven supply chain (e.g. FoodPrepare, with a high level of information integration to optimize the procurement of raw materials), Service-driven supply chain (e.g. LogisticService, achieving the system integration with suppliers to guarantee last mile distribution and multimodal transportation).

In this sense, we can argue that results provide an overview of the practices performed by a variety of companies of European supply chains, with each practice to be considered according to the company's context and aims (especially in terms of supply chain strategy). The groups of practices presented in Table 4 can represent a reference for companies aiming to shape their supply chains (in terms of structure, strategy or single objectives or performances) according to one or a combination of more supply chain strategies. 


\section{Conclusions}

Nowadays, macro-trends and sectoral-specific evolutions are changing the way companies produce, distribute and build relationships in their supply chain. Therefore, companies are required to properly design and manage their supply chain activities in order to reach the goals of effectiveness and efficiency, as well as to evolve towards more sustainable and resilient structures.

This chapter provided a study of multiple cases of excellence among European supply chains. A total of 18 cases have been investigated across 8 industries considered among the key ones for European economy, i.e. Automotive, Aerospace, Fashion, Chemical, IT, Distribution/logistics, Furniture, Food and Beverage. Related matching with the 10 supply chain strategies and best practices representing a reference for European supply chains are presented.

Results show that European industries are evolving in different ways according to their context-specific features, but their evolutions are mainly characterised by digitalization/adoption of enabling technologies, new business models (and value offers), and new roles and structures of the supply chain. Successful companies in each of these industries are shaping their processes along these directions, and activating one or a combination of supply chain strategies according to their main objectives. All cases are adopting practices for digitalization of all dimensions analysed in their supply chain, i.e. Products and services, Sourcing, Production process, Supply chain configuration, Customer relationship. Practices highlighted in each supply chain dimension regarding new business models (and processes to enact them) include: defining products and services portfolio and sustainability in products and services; cultivating excellence in operations according to specific priority areas, and including sustainability and efficiency in production processes;

Moreover, practices adopted by selected companies are driving new roles and structures of the supply chain, considering one or a combination of supply chain strategies. Examples of categories of practices are: outlining value chain and strategy, and processes supporting products and services development; supplier selection and evaluation; defining kind of relationship with suppliers, distributors/logistics providers, customers; cultivating relationships with suppliers and/or customers according to specific priority areas; design of production lines; specific processes for transportation and warehouses management, demand planning and forecasting and marketing; targeting downstream supply chain configuration according to specific priority areas.

As already highlighted, the same practice can be applied with a different scope according to the supply chain strategy which is aimed to be realized. In this sense, results of this multiple case study provided a wider and more practical perspective to be considered in the definition of the intervention priorities, policy actions and funding schemes aimed at sustaining European supply chains.

Due to the qualitative research design, the results from the analysis of the selected 18 cases can't be generalized to all European industries, but we can argue all of them are representative of many key practices highlighted in the selected sectors. Results 
summarised in Table 4 provide a reference of potential combinations of practices and enabling technologies to be considered by managers in their decision-making process to effectively and efficiently implement each supply chain strategy (or combination of two or more strategies) in their company and its supply chain.

Acknowledgements We are grateful to all contributors of the Next-Net project team and particularly to Ana Cristina Barros, Pedro Senna, Riccardo Zimmermann Victoria Muerza, Eva Thanous, Cemre Multu, Sebastien Balech, Saskia Sardesai. We also want to thank Laura Macchion and Andrea Vinelli from University of Padua and all the interviewees of the analysed companies. This work was financially supported by the European Union's Horizon 2020 Research and Innovation Program under the Grant Agreement No. 768884.

\section{References}

Acea (2018) The automobile industry pocket guide. https://www.acea.be/uploads/publications/ ACEA_Pocket_Guide_2018-2019.pdf. Accessed 26 Sept 2019

Acea (2019) Facts about the automobile industry. https://www.acea.be/automobile-industry/factsabout-the-industry. Accessed 26 Sept 2019

AeroSpace and Defence Industries Association of Europe (2018) Supply Chain. https://www.asdeurope.org/supply-chain. Accessed 26 Sept 2019

Atomico (2018) The State of European Tech 2018. https://2018.stateofeuropeantech.com/chapter/ state-european-tech-2018/article/welcome-state-european-tech-2018/. Accessed 26 Sept 2019

CBI (Centre for the Promotion of Imports from developing countries) (2016) CBI product factsheet: fast fashion in Europe. https://www.cbi.eu/sites/default/files/market_information/researches/pro duct-factsheet-europe-fast-fashion-2016.pdf. Accessed 26 Sept 2019

CB Insights (2018) Food and beverage trends 2019. Emerging trends. https://www.cbinsights.com/ research/food-beverage-trends-2019/. Accessed 26 Sept 2019

CEFIC-The European Chemical Industry Council (2017) Landscape of the European chemical industry 2018. Accessed 26 Sept 2019

CEFIC-The European Chemical Industry Council (2018) CEFIC facts and figures 2018. https:// cefic.org/app/uploads/2018/12/Cefic_FactsAnd_Figures_2018_Industrial_BROCHURE_T RADE.pdf. Accessed 26 Sept 2019

Certification Europe (2019) IT Sector. https://www.certificationeurope.com/industries/technical/. Accessed 26 Sept 2019

Cheater A (2017) Supply chain pain points in the aerospace and defense industry. https://blog. kinaxis.com/2017/08/supply-chain-pain-points-aerospace-defense-industry/. Accessed 26 Sept 2019

CMTC - California Manufacturing Technology Consulting (2019) Challenges and trends facing furniture manufacturers. https://www.cmtc.com/blog/furniture-manufacturing-challe nges-trends-2016. Accessed 26 Sept 2019

CompTIA - Computing Technology Industry Association (2019) IT Industry Outlook 2019. https:// www.comptia.org/resources/it-industry-trends-analysis. Accessed 26 Sept 2019

Cotance (2018) The European leather industry. https://www.euroleather.com/index.php/cotance/ the-european-leather-industry. Accessed 26 Sept 2019

Deloitte (2019) 2019 Technology Industry Outlook. https://www2.deloitte.com/us/en/pages/techno logy-media-and-telecommunications/articles/technology-industry-outlook.html. Accessed 26 Sept 2019 
DHL (2018) DHL logistik trend radar version 2018/2019. https://www.logistics.dhl/globalen/home/insights-and-innovation/thought-leadership/trend-reports/logistics-trend-radar.html. Accessed 26 Sept 2019

EFIC-European Furniture Industries Confederation (2019) Annual report 2019. https://9e2 160bf-a0b5-460b-aec7-e9af818978ee.filesusr.com/ugd/a1d93b_9562bbff681441519202c20a 45a802ec.pdf. Accessed 26 Sept 2019

EURATEX (European Apparel and Textile Confederation) (2017) Annual Report 2017. https:// euratex.eu/wp-content/uploads/2019/05/Euratex-annual-report-2017-LR.pdf. Accessed 26 Sept 2019

European Commission (2015a) Fact-finding studies in support of the development of an EU strategy for freight transport logistics: lot 1: analysis of the EU logistics sector. https://ec.europa.eu/transport/sites/transport/files/themes/strategies/studies/doc/2015-01freight-logistics-lot1-logistics-sector.pdf. Accessed 26 Sept 2019

European Commission (2015b) Textiles and clothing in the EU. https://ec.europa.eu/growth/sec tors/fashion/textiles-clothing/eu_en. Accessed 26 Sept 2019

European Commission (2019a) Automotive industry. https://ec.europa.eu/growth/sectors/automo tive_en. Accessed 26 Sept 2019

European Commission (2019b) Food 2030. https://ec.europa.eu/research/bioeconomy/index.cfm? pg=policy\&lib=food2030. Accessed 26 Sept 2019

European Confederation of the Footwear Industry (2018) Key facts and figures. http://cec-footwe arindustry.eu/sector/key-facts-and-figures/. Accessed 26 Sept 2019

Eurostat (2017) Annual detailed enterprise statistics for services. https://ec.europa.eu/eurostat/statis tics-explained/index.php/Transportation_and_storage_statistics_-_NACE_Rev_2. Accessed 26 Sept 2019

Eurostat (2018) Manufacturing statistics-NACE Rev. 2. https://ec.europa.eu/eurostat/statisticsexplained/index.php/Manufacturing_statistics_-_NACE_Rev._2. Accessed 26 Sept 2019

Eurostat (2019) Eurostat database. https://ec.europa.eu/eurostat/data/database. Accessed 26 Sept 2019

FoodDrinkEurope (2019a) Data and Trend EU food and drink industry 2018. https://www.fooddr inkeurope.eu/uploads/publications_documents/FoodDrinkEurope_Data_and_Trends_2018_F INAL.pdf. Accessed 26 Sept 2019

FoodDrinkEurope (2019b) FoodDrinkEurope's views on Horizon Europe. https://www.fooddrink europe.eu/publication/fooddrinkeuropes-views-on-horizon-europe/. Accessed 26 Sept 2019

Fornasiero R, Marchiori I, Pessot E, Zangiacomi A, Sardesai S, Barros AC, Thanous E, Weerdmeester R, Muerza V (2020) Paths to innovation in supply chains: the landscape of future research. In: Fornasiero et al (ed) Next generation supply chains: a roadmap for research and innovation, Springer

Fredriksson G, Roth R, Tagliapietra S, Veugelers R (2018) Is the European automotive industry ready for the global electric vehicle revolution? Policy Contr 26:1-21

International Labour Organization (2016). Sectoral studies on decent work in global supply chains. https://www.ilo.org/wcmsp5/groups/public/—ed_dialogue/—sector/documents/ publication/wcms_485367.pdf. Accessed 26 Sept 2019

ITI (Information Technology Industry Council). (2019). https://www.itic.org/. Accessed 26 Sept 2019

Konrad K, Stagl S (2018) Competitiveness of the European automotive manufacturing industry. Institute for Innovation and Technology (IIT), https://www.iit-berlin.de/en/publications/compet itiveness-of-the-european-automotive-manufacturing-industry. Accessed 26 Sept 2019

McKinsey Apparel, Fashion \& Luxury Group (2018) Is apparel manufacturing coming home? Nearshoring, automation, and sustainability - establishing a demand-focused apparel value chain. https://www.mckinsey.com/ /media/mckinsey/industries/retail/our\%20insights/is\%20a pparel $\% 20$ manufacturing $\% 20$ coming $\% 20$ home/is-apparel-manufacturing-coming-home_vf. pdf. Accessed 26 Sept 2019 
Miller R (2018) Why supply chain management is important in aerospace and defense. https:// www.ey.com/en_gl/aerospace-defense/why-supply-chain-management-is-important-in-aerosp ace-and-defense. Accessed 26 Sept 2019

PwC (2019) PwC CEE Transport and Logistics Trend Book 2019. https://www.pwc.pl/pl/pdf/pub likacje/2018/transport-logistics-trendbook-2019-en.pdf. Accessed 26 Sept 2019

Roland Berger (2015) The supply chain excellence study. Accessed 26 Sept 2019

Roland Berger (2017) Additive manufacturing in aerospace and defense. Accessed 26th September 2019

Statista (2017) Apparel and clothing market Europe — statistics and facts. https://www.statista.com/ topics/3423/clothing-and-apparel-market-in-europe/. Accessed 26 Sept 2019

Worldfurniture (2019) The European market for wooden furniture components. https://www.wor ldfurnitureonline.com/research-market/the-european-market-wooden-furniture-components0058485.html. Accessed 26 Sept 2019

Yin RK (2013) Case study research: design and methods, 5th edn. SAGE Publications, Thousand Oaks

Open Access This chapter is licensed under the terms of the Creative Commons Attribution 4.0 International License (http://creativecommons.org/licenses/by/4.0/), which permits use, sharing, adaptation, distribution and reproduction in any medium or format, as long as you give appropriate credit to the original author(s) and the source, provide a link to the Creative Commons license and indicate if changes were made.

The images or other third party material in this chapter are included in the chapter's Creative Commons license, unless indicated otherwise in a credit line to the material. If material is not included in the chapter's Creative Commons license and your intended use is not permitted by statutory regulation or exceeds the permitted use, you will need to obtain permission directly from the copyright holder.

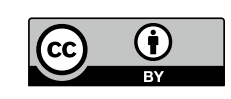

